Aloma 2017, 35(2), 23-37

Revista de Psicologia, Ciències de l’Educació i de l'Esport

ISSN: $1138-3194$

Copyright @ 2017

www.revistaaloma.net

\title{
Negative attitudes towards borderline personality disorder patients in Spanish mental health and primary care services: mHealth, a possible solution?
}

\author{
Eudald Castell \\ Ramon Llull University
}

Received: 20-9-2017

Accepted: 24-10-2017

Negative attitudes towards borderline personality disorder patients in Spanish mental

Summary. The purpose of this project was to study negative attitudes exhibited by mental health professionals toward patients with Borderline Personality Disorder (BPD) as a function of their work area (general health vs. mental health), profession, the quantity of patients with BPD they have treated over the past year, their number of years of experience in mental health, and their gender. The study used a sample of 310 professionals. We also explored how the professionals' interest in using an innovative technological application (Medtep DBT) interacted with some of these variables, as well as the potential of the application to help change negative attitudes. Significant differences in attitude were found based on work area, profession, quantity of patients with BPD treated over the past and gender. Furthermore, profession, number of patients and years of experience in mental health determined significant differences in the professionals' degree of interest in using Medtep DBT. Moreover, those with higher negative attitudes showed less interest in the application and a lesser willingness to try it. These results highlight the need to keep investigating how to improve the attitudes of healthcare professionals, especially nursing staff and general practitioner, since they appear to be more susceptible to the development of negative attitudes. As a conclusion, we infer that the lack of empathy towards patients with BPD, the difficulties in their treatment and the years of experience in mental health all act as barriers to the implementation of the application.

Key words: Borderline Personality Disorder; negative attitudes; mental health professionals; mHealth; mobile applications

Actituds negatives envers pacients amb trastorn límit de la personalitat als serveis de salut mental i d'assistència primària espanyols: mHealth, una possible solució?

\begin{abstract}
Resum. L'objectiu d'aquest estudi ha estat investigar les actituds negatives de professionals de la salut mental envers pacients amb Trastorn Límit de la Personalitat (TLP) en funció de la seva àrea de treball, la seva professió, pacients amb TLP tractats al darrer any, anys d'experiència en salut mental i sexe en una mostra de 310 professionals. A més a més s'han explorat, en base a part d'aquestes mateixes variables, el seu interès a usar una aplicació tecnològica innovadora (Medtep DBT) per al tractament d'aquests pacients així com la possibilitat que aquesta servís per a reduir les possibles actituds negatives. S'han trobat diferències significatives en les actituds en funció de l'àrea de treball, la professió, el nombre de pacients amb TLP tractats el darrer any i el sexe. La professió, el nombre de pacients i els anys d'experiència en salut mental també han determinat diferències significatives quant a l'interès a usar Medtep DBT. Aquells professionals amb majors actituds negatives han mostrat un menor interès i una menor disposició a utilitzar l'aplicació. Aquests resultats demostren la necessitat de seguir investigant com millorar les actituds d'aquests professionals, especialment dels d'infermeria i dels metges de capçalera, en ser els més vulnerables a desenvolupar-les. Com a conclusió es poden assenyalar la falta d'empatia envers pacients amb TLP, les dificultats en el seu tractament $i$ els anys d'experiència en salut mental com a barreres en la implementació de l'aplicació.
\end{abstract}

Paraules clau: Trastorn Límit de la Personalitat; actituds negatives; professionals de la salut mental; mHealth; aplicacions mòbils

Correspondence:

Eudald Castell Panisello

FPCEE Blanquerna, Universitat Ramon Llull

c/Císter, 34, 08022 Barcelona

Email: eudaldcp@blanquerna.url.edu 


\section{Introduction}

Borderline Personality Disorder (BPD) is a cluster B personality disorder that is usually diagnosed at the beginning of adulthood; it is characterized by interpersonal hypersensitivity, affective dysregulation, high impulsivity, identity disturbance and self-harm and suicidal behaviours (American Psychiatric Association [APA], 2013). Because of this symptomatology, health professionals (HPs) usually consider dealing with these patients to be more difficult than treating patients with other kinds of symptomatology (Cleary, Siegfried \& Walter, 2002). The importance of this phenomenon is thrown into relief by the fact that the global prevalence of BPD is between $0.7 \%$ and $5.9 \%$ (Coid, Yang, Tyrer, Roberts \& Ullrich, 2006; Grant et al., 2008; Lenzenweger, Lane, Loranger \& Kessler, 2007; Tomko, Trull, Wood \& Sher, 2014; Torgersen, Kringlen \& Cramer, 2001; Trull, Jahng, Tomko, Wood \& Sher, 2010; Zanarini et al., 2011).

These professionals also tend to cite the frequent use of health services made by BPD patients as a factor influencing how they view these individuals (Quirk et al., 2015; Zanarini, Frankenburg, Hennen \& Silk, 2004); these patients are more likely than others to cycle through all kinds of psychosocial therapy, except for self-help groups, and they tend to take even more types of medication that patients diagnosed with major depressive disorder (Bender et al., 2001). Powers and Oltmanns (2012) also found a positive correlation between personality disorder scores, especially for cluster $\mathrm{B}$, and use of health care services and medication. Given the high frequency of contact between HPs and BPD patients (Cleary, et al., 2002), it is no wonder that several studies have analyzed how these professionals feel toward these patients. This is an important matter, especially in light of the kind of symptomatology they must face (Piccinino, 1990). It has been shown that the simple act of labeling patients as BPD can result in HPs being more negative and less empathic in the treatment they offer (Fraser \& Gallop, 1993; Gallop, Lancee \& Garfinkel, 1989; Markham \& Trower, 2003). In this same situation, psychiatrists tend to overrate the severity of the patients' symptoms (Lam, Salkovskis \& Hogg, 2016). In another study, several HPs reported observing BPD traits in patients who had been misdiagnosed with the disorder; they also reported that those same patients showed a low degree of effort toward self-help. This was not reported by HPs who knew that the correct diagnosis was not BPD (Lam, Poplavskaya, Salkovskis, Hogg $\&$ Panting, 2016). It is also worth noting that HPs tend to experience even more difficulties when dealing with BPD patients than they do when treating patients with other personality disorders (Eren \& Sahin, 2016).

\section{Health care professionals' attitudes towards their patients}

The triarchic model of attitudes, first used by Smith (1947), comprises three components of attitudes: an affective, a cognitive and a behavioral component. Later, Breckler (1984) defined attitude as "a response to an antecedent stimulus or attitude object" (p.1191). According to Breckler,

"Affect refers to an emotional response, a gut reaction, or sympathetic nervous activity, (...). Behavior includes overt actions, behavioral intentions, and verbal statements regarding behavior. Beliefs, knowledge structures, perceptual responses, and thoughts constitute the cognitive component." (p.1191)

In subsequent studies, particularly high consistency has been found between the affective and cognitive factors and the behavioral response (Petty, Wegener \& Fabrigar, 1997).

Many studies have investigated HP attitudes towards BPD patients (Arora, 2016), with nurses having been the most frequently analyzed professional collective (Deans \& Meocevic, 2006; Forsyth, 2007; Fraser \& Gallop, 1993, Giannouli, Perogamvros, Berk, Svigos \& Vaslamatzis, 2009; Hauck, Harrison \& Montecalvo, 2013; James \& Cowman, 2007; Lancee \& Garfinkel, 1989; Markham 2003; Markham \& Trower 2003; McGrath \& Dowling, 2012; O'Conell \& Dowling, 2013; Woollaston \& Hixenbaugh, 2008), followed by mixed samples of HPs (Black et al., 2011, Bodner, CohenFridel \& Iancu, 2011; Bodner et al., 2015; Cleary et al., 2002; Commons \& Lewis, 2008; Imbeau, Bouchard, Terradas \& Simard, 2014; Krawitz \& Batcheler, 2006) and then therapists (Bourke \& Grenyer, 2010; Jobst, Hörz, Birkhofer, Martius \& Rentrop, 2010; Servais \& Saunders, 2007).

The above-mentioned studies were carried out in locations including United States (Black et al., 2011), Israel (Bodner et al, 2015), New Zealand (Commons \& Lewis, 2008) and Australia (Cleary et al., 2002) and others, but no such study has been done in Spain, nor have any studies compared the attitudes of professionals from different countries, and this despite some evidence suggesting that some differences may exist. Stefanovics et al. (2016) compared the attitudes toward mental illness of HPs in five different countries and found significant differences; hence, it could be interesting to obtain results from a Spanish sample.

Beyond this lack of intercultural studies, there are also few studies comparing different healthcare areas; Commons and Lewis (2008) compared the attitudes of professionals from mental health areas (MHPs) with those of emergency medical professionals. Imbeau et al. (2014) compared medical residents, general practitioners (GP), and other MHPs, but they did not conduct a differential analysis for the groups. Studies including primary care professionals (PCHPs) are uncommon, a gap that takes on even more relevance given the realities that up to $6 \%$ of the patients that visit primary care centres suffer from BPD (Gross et al., 2002), that these patients tend to visit a series of different GPs (Saonse, Farukhi \& Wiederman, 2011), and 
that they present highly challenging symptoms (Sansone \& Sansone, 1995). Also, despite the fact that studies in this field have most often (apart from looking at professional variables) examined the variables of gender, number of BPD patients treated in the last year and years of experience in mental health, the existing research has yet to unable to clarify the influence of these variables on HP attitudes. Commons and Lewis (2008), for instance, found no differences in terms of contact with BPD patients nor in terms of experience in mental health, but women turned out to hold more positive attitudes than men. Black et al. (2011) concluded that those who had treated a higher number of BPD patients in the last year and had more experience expressed more positive attitudes. Lastly, Bodner et al. (2011) found no differences regarding gender and years of experience, but did find them in terms of the number of patients seen in the last year. Based on this data, the present study represents an effort to clarify the role of these variables in HPs' attitudes toward BPD patients. With respect to gender, there is a huge amount of literature indicating that female HPs show greater levels of empathy towards their patients in general (Hojat, 2016). Based on this body of research, we hypothesize that having treated more BPD patients in the last year, having worked for a shorter time in the mental health field and being male will translate into more negative attitudes towards these patients.

\section{Consequences of attitudes}

The existence of negative attitudes towards BPD patients has already been observed by several studies (Dickens, Lamont \& Gray, 2016; Sansone \& Sansone, 2013), and it has been shown to sometimes lead to certain harmful consequences for the patients on different levels (Rogers \& Dunne, 2011). This is true from a theoretical point of view, due to the high degree of consistency between attitude and behavior (Petty et al., 1997). It has also been borne out in practice, as patients have been shown to be aware of the professionals' attitudes toward them (Rogers \& Dunne, 2011), which can lead to a further devaluation of the patients' self-image (Veysey, 2014) and to decreased willingness to seek help (Lawn \& McMahon, 2015). Given the interpersonal issues BPD patients usually have, it is essential for them to feel valued, understood and accepted, because these are aspects that influence greatly the therapeutic relationship (Katsakou \& Pistrang, 2017). These consequences brought to the fore a need for methods to reduce negative attitudes (Bodner et al., 2015; O'Conell \& Dowling, 2013). These methods have normally taken the form of educational programs (Commons, 2009), workshops (Hazelton, Rossiter \& Milner, 2006; Shanks, Pfohl, Blum \& Black, 2011; Keuroghlian et al., 2016; Knaak, Szeto, Fitch, Modgill \& Patten, 2015; Krawitz, 2004) or training sessions (Herschell, Lindhiem, Kogan, Celedonia \& Stein, 2014).

\section{Mobile Internet-based applications in healthcare (mHealth)}

mHealth (Mobile Health) is a concept that can be defined as the use of mobile applications in the health sector (Qiang, Yamamichi, Hausman, Miller \& Altman, 2012). The mHealth field has emerged as a sub-segment of eHealth, the use of information and communication technology (ICT), such as computers, mobile phones, communications satellites, patient monitors, etc., in health services and information. mHealth applications include the use of mobile devices in the collection of community and clinical health data, the delivery of healthcare information to practitioners, researchers, and patients, the real-time monitoring of patients' vital signs, and the direct provision of care (via mobile telemedicine) (Wikipedia).

Many reports have pointed to the potential of mHealth and foretold a great future for it, both in general terms (Silva, Rodrigues, Díez, López-Coronado \& Saleem, 2015; Leigh \& Flatt, 2015; Price et al., 2014; PricewaterhouseCoopers [PwC], 2012; Torous \& Powell, 2015; Kazdin \& Blasé, 2011) and more specifically in the mental health field (Harrison et al., 2011; Marzano et al., 2015; Price et al., 2014; Torous, Staples \& Onnela, 2015), in which a range of studies with promising outcomes have already been published (Torous, Levin, Ahern \& Oser, 2017). An indication of the strength of the phenomenon is the increased presence of mHealth apps in the main mobile application markets (Google Play and Apple Store); while as recently as 2014 there were less than 100.000 mHealth applications (research2guidance, 2014), by 2016 this number had shot up to 150.000 (research2guidance, 2016). However, this increase must be viewed with a degree of skepticism, as the existence of such a great number of applications might imply that most of them are not properly validated and lack of any kind of proven efficacy, which in many cases is absolutely necessary, depending on the ultimate use of the apps (Marley \& Farooq, 2015; Olff, 2015; Powell, Landman \& Bates, 2014; Price et al., 2014; Tomlinson, Roterham-Borus, Swartz \& Tsai, 2013; World Health Organization [WHO], 2011).

The present study uses an existing mobile application and web platform called Medtep DBT (Suñol et al., 2017), which was created by three psychologists and three psychiatrists, who also tested its content validity and piloted it in order to assess its efficacy. It is based on Dialectical Behaviour Therapy (DBT) (Linehan, 1987), a widely used therapy for BPD patients with proven efficacy (Cristea et al., 2017) both in individual and group therapy (Linehan et al., 2015), especially for reducing self-harm behaviors (Panos, Jackson, Hasan \& Panos, 2014). Medtep DBT allows patients to $\log$ in to the application and use its diary feature to register all their emotions, emergencies, the DBT skills used, medication intake and crises suffered; all this is then automatically shared with the HP in charge of the patient, who receives all the information in a summarized and understandable format. The professionals 
have access to this data through the web platform, and they can also access their patients' crisis plans. Consequently, Medtep DBT is aimed both at patients (through the mobile version) and at therapists (through the web platform). We believe that getting all this information might help HPs better understand their patients and diminish their negative attitudes towards them. In recent studies it has been observed that there is a high degree of interest among psychiatric patients in using mHealth to monitor their health (Torous et al., 2014; Torous, Friedman \& Keshavan, 2014). Likewise, several HPs have started implementing different mHealth tools in their work practices (Braun, Catalani, Wimbush \& Israelski, 2013), and there is already some knowledge about the facilitators and barriers that condition the use of mHealth by these professionals (Gagnon, Ngangue, Payne-Gagnon \& Desmartis, 2016) and their patients (Graves, Doucet, Dubé \& Johnson, 2017). Particularly in the mental health field, many innovations and mHealth tools have emerged, including some for severe mental health disorders (Naslund, Marsch, McHugo \& Bartels, 2015) and others for behavior interventions (Luxton, McCann, Bush, Mishkind \& Reger, 2011), with Medtep DBT being one of the latter category.

Before introducing an innovative technology like Medtep DBT, however, it is advisable to assess the professionals' perception of its usefulness as well as their willingness to apply it (Greenhalgh, Robert, MacFarlane, Bate \& Kryiakidou, 2004). This means studying the extent to which the HPs believe that this new tool will be useful and whether they would use it knowing only a brief description of it. This procedure has already been used previously for another mobile application (Kuhn, 2014).

\section{The present study}

The aim of this study is to analyze (negative) attitudes of various groups of healthcare professionals towards BPD patients and to gather data on indicators of whether a specific e-health application might be a valid tool to help change these negative attitudes. We wanted to compare health professionals working in different areas (mental health versus general health) and in different professions (psychologists, psychiatrists and psychiatric nurses representing MHPs, GPs and head nurses representing PCHPs) with respect to their attitudes. We also wanted to know if the attitudes depend on the number of patients treated and on the years of experience, since in earlier studies it was not clear what role these variables played (Commons and Lewis, 2008; Black et al., 2011; Bodner et al., 2011).

At the same time, we wanted to assess the perception on the part of HPs of the use of Medtep DBT, dividing them into the same categories. Since Medtep DBT is based on DBT, a method of therapy conducted by psychologists and, to a lesser degree psychiatrists, we wanted to know if these professionals had a different perception than the others.
Finally, our study attempts to analyze whether negative attitudes towards BPD patients and the perception of the use of Medtep DBT are related. HPs with more negative attitudes may be more open to new tools, such as Medtep DBT, since they might have a greater wish to decrease these attitudes.

These objectives can be translated into the following three hypotheses:

H1: There will be more negative attitudes towards BPD patients among HP who a) work in primary care than among those who work in mental health settings, b) have treated more BPD patients during the last year, c) have fewer years of experience in mental health, and d) are male.

H2: There will be a more favorable perception of using Medtep DBT among a) psychiatrists and psychologists than among other HP, b) those who have treated more BPD patients c) those who are less experienced (in terms of years) in the mental health field.

H3: There will be a significant correlation between negative attitudes and perception of using Medtep DBT.

\section{Method}

\section{Participants and procedure}

Participants were professionals from 10 Spanish mental health centers and primary care areas (one from Aragon, three from Castilla-La Mancha, one from Castile and León and five from Catalonia). Inclusion criteria were based on the ones used by Bodner et al. (2011) and consisted of requirements that participants: a) have at least a year of experience in the mental health field, b) work in a public health institution, c) be a GP, head nurse, psychiatric nurse, psychologist or psychiatrist. The questionnaires were handed out to a total of twelve collaborators who then distributed them among the eligible professionals at their centers. 64\% of the sample answered the questionnaires, with the final sample for the study consisting of $310 \mathrm{HP}$. The distributions and characteristics of the sample are depicted in table 1 .

Participation was voluntary. Participants were informed about the nature of the study and signed an informed consent.

\section{Material}

A total of three questionnaires were administrated in the following order:

Sociodemographic data questionnaire: Participants were asked to indicate their age, gender, profession, years of experience in the mental health field and number of BPD patients treated in the last year.

Borderline Patients-Emotional Attitudes Inventory; BPEAI (Bodner et al., 2011): This questionnaire assesses the HPs' emotional attitudes towards BPD patients. It has 20 items answered on a five-point Likert scale, according to degree of agreement. It contains three fac- 
Table 1. Description of the sample: frequencies and percentages (in parentheses)

\begin{tabular}{|c|c|c|c|c|c|c|}
\hline & \multicolumn{2}{|c|}{$\begin{array}{c}\text { PCHP } \\
(n=131)\end{array}$} & \multicolumn{3}{|c|}{$\begin{array}{c}\text { MHP } \\
(n=179)\end{array}$} & \multirow[b]{2}{*}{$\begin{array}{l}\text { Total } \\
(n=310)\end{array}$} \\
\hline & $\begin{array}{l}\text { Head Nurse } \\
(n=65)\end{array}$ & $\begin{array}{l}\text { GP } \\
(n=66)\end{array}$ & $\begin{array}{l}\text { Psychiatric Nurse } \\
(n=56)\end{array}$ & $\begin{array}{l}\text { Psychologist } \\
(n=62)\end{array}$ & $\begin{array}{l}\text { Psychiatrist } \\
(n=61)\end{array}$ & \\
\hline \multicolumn{7}{|l|}{ Gender* } \\
\hline Men & $18(27.7)$ & $33(50)$ & $5(8.9)$ & $18(29)$ & $28(45.9)$ & $102(32.9)$ \\
\hline Women & $47(72.3)$ & $33(50)$ & $51(91.1)$ & $43(69.4)$ & $33(54.1)$ & $207(66.8)$ \\
\hline \multicolumn{7}{|c|}{ Years of experience } \\
\hline $1-4$ & $14(21.5)$ & 7 (10.6) & $13(23.2)$ & $11(17.7)$ & $5(8.2)$ & $50(16.1)$ \\
\hline $5-10$ & $10(15.4)$ & $14(21.2)$ & $13(23.2)$ & $16(25.8)$ & $20(32.8)$ & $73(57.7)$ \\
\hline $11-19$ & $16(24.6)$ & $10(15.3)$ & $15(26.8)$ & $18(29)$ & $17(27.9)$ & $76(24.5)$ \\
\hline$>20$ & $25(38.5)$ & $35(53)$ & $15(26.8)$ & $17(27.4)$ & $19(31.1)$ & $111(35.8)$ \\
\hline \multicolumn{7}{|c|}{ BPD patients in the last year } \\
\hline $0-2$ & $11(16.9)$ & $3(4.5)$ & $3(5.4)$ & $14(22.6)$ & $0(0)$ & $31(10)$ \\
\hline $3-9$ & $43(66.2)$ & $41(62.1)$ & $31(55.4)$ & $18(29)$ & $17(27.9)$ & $150(48.4)$ \\
\hline $10-24$ & $10(15.4)$ & $20(30.3)$ & 19 (33.9) & $21(33.9)$ & $25(41)$ & 95 (30.6) \\
\hline$>25$ & $1(1.5)$ & $2(3)$ & $3(5.4)$ & 9 (14.5) & $19(31.1)$ & $34(11)$ \\
\hline
\end{tabular}

Note: * 1 participant did not report gender $(0.3 \%)$

tors: "negative emotions", which refers to the negative emotional attitudes that HPs experience when dealing with BPD patients (e.g. "I feel angry when a BPD patient threatens to commit suicide"); "treatment difficulties", which reflects the difficulties experienced by HPs when dealing with BPD patients (e.g. "It is difficult for me to treat BPD patients"); and "empathy", which refers to the level of empathic feelings HPs hold towards BPD patients (e.g, "I feel empathy toward BPD patients"). The items of the latter factor were scored in reverse in order to obtain a score for "lack of empathy") (after personal consultations with E. Bodner). The BP-EAI was translated and adapted into Spanish using the reverse translation method (Brislin, 1970) following the guidelines proposed by Muñiz, Elosua and Hambleton (2013) in order to minimize the differences between the original test and the translated version. To ensure the correct comprehension of the inventory and to correct any possible mistakes made in the translation process, a pilot sample $(n=5)$ tested it. Based on the feedback received, minor changes were introduced. The internal consistency of the factors was calculated using Cronbachs $\alpha$, resulting in similar values to those of the original study: $\alpha=.93$ for the negative emotions factor, $\alpha=.78$ for the treatment difficulties factor, and $\alpha=.63$ for the lack of empathy factor.

Questionnaire of Perception of Using Medtep DBT (Cuestionario de percepción de uso, CPU): This questionnaire was created adhoc and assesses the respondent's perception of use of the application Medtep DBT. It has 19 items to be answered on a seven-point Likert scale according to the degree of agreement. The items are designed to represent previously identified barriers and facilitators for the implementation of mHealth, such as perceived usefulness, perceived ease of use, applicability based on the patient's characteristics or temporal availability and other factors (see Gagnon et al., 2016). The format of the items is based on Kuhn et al. (2014), who assessed the perception of using of another mobile application. Since the participants had not used the application yet, we chose to present them with a brief description of the application, adding several screenshots of all the displays the professional would see when using the application. Like with the BP-EAI, the CPU was first presented to a pilot sample $(n=5)$ to ensure comprehension. Based on the feedback received, minor changes were introduced. Also, an exploratory factor analysis (EFA) was run (see Table 2). Conditions for EFA were given $\left(K M O=0.924 ; \chi^{2}=4360.181 ; g l=\right.$ $171 ; p<.0001)$. The results yielded a total of three factors with an explanatory variance of $67.51 \%$. The first factor, called "usefulness of Medtep DBT" (45.64\% of explained variance; $\alpha=.92$ ), referred to the general usefulness of the application in treating BPD patients. It contained nine items. The second factor, "change of attitudes" (13.81\% of explained variance; $\alpha=.93)$ reflected the estimated possibility of the application to modify the HPs' attitudes toward BPD patients; this factor contains six items based on some BP-EAI items connected to the presence of negative attitudes towards BPD patients. The third factor, with four items, is called "intention of using Medtep DBT" (8.05\% of explained variance; $\alpha=.66$ ), and it refers to the participants' intentions of introducing the application into their daily practice. A "total CPU score" ( $\alpha=.923)$ was also calculated, representing a general perception of the usefulness and possible introduction of the application in their work practice. It must be highlighted that in future research, special attention should be given to a total of three items due to their low total corrected correlations $(r<.4)$ : item 4 (.237), item $11(.290)$ and item 5 (.237).

\section{Data analysis}

Data were analyzed with SPSS Statistics version 24 . First, the participants' answers to the items "years of professional experience" and "number of patients" were 
Table 2. Rotated component matrix of the CPU exploratory analysis

\begin{tabular}{|c|c|c|c|}
\hline Items & $\begin{array}{l}\text { Usefulness of } \\
\text { Medtep DBT }\end{array}$ & $\begin{array}{l}\text { Change of } \\
\text { Attitudes }\end{array}$ & $\begin{array}{l}\text { Intention to use } \\
\text { Medtep DBT }\end{array}$ \\
\hline \multirow{2}{*}{$\begin{array}{l}\text { 8. Conocer las emociones que suele experimentar un/a paciente con TLP podría } \\
\text { serme útil a la hora de tratarlo } \\
\text { [Knowing the emotions usually experienced by BPD patients may be useful to me } \\
\text { when treating them] }\end{array}$} & .849 & .197 & .138 \\
\hline & & & \\
\hline \multirow{2}{*}{$\begin{array}{l}\text { 12. Conocer de que forma un/a paciente con TLP se tranquiliza cuando sufre una } \\
\text { crisis a través del plan de crisis podría resultarme útil a la hora de tratarlo/a } \\
\text { [Knowing how a BPD patient reassures himself when he suffers a crisis through } \\
\text { the crisis plan may be useful to me when treating him] }\end{array}$} & .825 & .178 & .007 \\
\hline & & & \\
\hline \multirow{2}{*}{$\begin{array}{l}\text { 7. Conocer el tipo de urgencias que suele tener un/a paciente con TLP podría } \\
\text { resultarme útil a la hora de tratarlo } \\
\text { [Knowing what kind of urgencies a BPD patient tends to suffer may be useful to } \\
\text { me when treating him] }\end{array}$} & .824 & .181 & .190 \\
\hline & & & \\
\hline \multirow{2}{*}{$\begin{array}{l}\text { 10. Conocer la estructura (los } 7 \text { pasos del análisis de cadena) de las crisis sufridas por } \\
\text { un paciente con TLP podría resultarme útil a la hora de tratarlo/a } \\
\text { [Knowing the structure (the } 7 \text { steps of the chain analysis) of the suffered crisis by } \\
\text { a BPD patient may be useful to me when treating him] }\end{array}$} & .820 & .281 & .189 \\
\hline & & & \\
\hline \multirow{2}{*}{$\begin{array}{l}\text { 13. Disponer de toda la información que proporciona Medtep DBT sobre un/a paciente } \\
\text { con TLP me ayudaría a comprender mejor sus comportamientos problemáticos } \\
\text { [Having all the information Medtep DBT provides about a BPD patient may help } \\
\text { me to understand their problematic behaviors] }\end{array}$} & .815 & .279 & .204 \\
\hline & & & \\
\hline \multirow{2}{*}{$\begin{array}{l}\text { 9. Conocer que tipo de habilidades o que habilidades específicas de la Terapia } \\
\text { Dialéctico-Conductual usa un/a paciente con TLP podría serme útil a la hora } \\
\text { de tratarlo/a } \\
\text { [Knowing what kind of skills or DBT specific skills a BPD patient uses may be } \\
\text { useful to me when treating him] }\end{array}$} & .728 & .212 & .188 \\
\hline & & & \\
\hline \multirow{2}{*}{$\begin{array}{l}\text { 1. Estaría dispuesto/a a consultar los registros de Medtep DBT antes de atender un/a } \\
\text { paciente registrado/a en ella } \\
\text { [I would be willing to consult the Medtep DBT records before attending a } \\
\text { registered patient] }\end{array}$} & .688 & .186 & .411 \\
\hline & & & \\
\hline $\begin{array}{l}\text { 6. Medtep DBT me sería útil en general para tratar pacientes con TLP } \\
\text { [Medtep DBT may be useful to me in general when treating BPD patients] }\end{array}$ & .671 & .231 & .433 \\
\hline \multirow{2}{*}{$\begin{array}{l}\text { 11. Conocer el patrón de toma de medicamentos de un/a paciente con TLP podría } \\
\text { resultarme útil a la hora de tratarlo/a } \\
\text { [Knowing the pattern of medication taking of a BPD patient may be useful to me } \\
\text { when treating him] }\end{array}$} & .637 & .000 & -.314 \\
\hline & & & \\
\hline \multirow{2}{*}{$\begin{array}{l}\text { 16. Disponer de toda la información que proporciona Medtep } D B T \text { sobre un/a paciente } \\
\text { con TLP me ayudaría a no perder los estribos tan fácilmente a la hora de tratarlo/a } \\
\text { [Having all the information Medtep DBT provides about a BPD patient may help } \\
\text { me not losing my temper so easily when treating him] }\end{array}$} & .151 & .888 & .119 \\
\hline & & & \\
\hline \multirow{2}{*}{$\begin{array}{l}\text { 17. Disponer de toda la información que proporciona Medtep } D B T \text { sobre un/a paciente } \\
\text { con TLP me ayudaría a disminuir el nivel de emociones negativas que siento a la } \\
\text { hora de tratarlo/a } \\
\text { [Having all the information Medtep DBT provides about a BPD patient may help } \\
\text { me diminishing the negative emotions I experience when treating him] }\end{array}$} & .189 & .881 & .129 \\
\hline & & & \\
\hline \multirow{2}{*}{$\begin{array}{l}\text { 19. Disponer de toda la información que proporciona Medtep DBT sobre un/a paciente } \\
\text { con TLP me ayudaría a sentirme menos incómodo/a a la hora de tratarlo/a } \\
\text { [Having all the information Medtep DBT provides about a BPD patient may help } \\
\text { me feeling less impatient when treating him] }\end{array}$} & .176 & .859 & .082 \\
\hline & & & \\
\hline \multirow{2}{*}{$\begin{array}{l}\text { 15. Disponer de toda la información que proporciona Medtep } D B T \text { sobre un/a paciente } \\
\text { con TLP me ayudaría a no enfurecerme tan fácilmente a la hora de tratarlo/a } \\
\text { [Having all the information Medtep DBT provides about a BPD patient may help } \\
\text { me not getting furious so easily when treating him] }\end{array}$} & .234 & .846 & .163 \\
\hline & & & \\
\hline \multirow{2}{*}{$\begin{array}{l}\text { 18. Disponer de toda la información que proporciona Medtep } D B T \text { sobre un/a paciente } \\
\text { con TLP me ayudaría a no agotarme tan fácilmente a la hora de tratarlo } \\
\text { [Having all the information Medtep DBT provides about a BPD patient may help } \\
\text { me not wearing out so easily when treating him] }\end{array}$} & .138 & .792 & .197 \\
\hline & & & \\
\hline \multirow{2}{*}{$\begin{array}{l}\text { 14. Disponer de toda la información que proporciona Medtep DBT sobre un/a paciente } \\
\text { con TLP me permitiría sentir más empatía hacia él/ella } \\
\text { [Having all the information Medtep DBT provides about a BPD patient may help } \\
\text { me holding more empathy towards him] }\end{array}$} & .441 & .641 & .135 \\
\hline & & & \\
\hline \multirow{2}{*}{$\begin{array}{l}\text { 4. No usaría Medtep DBT, porque no creo que los/las pacientes vayan a registrar toda } \\
\text { su información en la aplicación móvil } \\
\text { [I would not use Medtep DBT since I do not believe that the patients will register } \\
\text { all their information in the mobile application] }\end{array}$} & -.088 & .133 & .727 \\
\hline & & & \\
\hline \multirow{2}{*}{$\begin{array}{l}\text { 3. No usaría Medtep DBT, porque no dispondría de tiempo para consultar los } \\
\text { registros del paciente } \\
\text { [I would not use Medtep DBT since I would not have the time to check the records } \\
\text { of the patient] }\end{array}$} & .475 & .187 & .653 \\
\hline & & & \\
\hline \multirow{2}{*}{$\begin{array}{l}\text { 5. La dificultad en la interpretación de la información proporcionada por Medtep } \\
D B T \text { me supondría un obstáculo para hacer uso de ella } \\
\text { [The difficulty in the interpretation of the information provided by Medtep DBT } \\
\text { would be an obstacle for me to make use of it] }\end{array}$} & .143 & .045 & .589 \\
\hline & & & \\
\hline \multirow{2}{*}{$\begin{array}{l}\text { 2. Me supondría un esfuerzo extra significativo tener que consultar Medtep DB } \\
\text { a lo largo de mi actividad laboral } \\
\text { [It would be an extra significant effort for me having to check Medtep DBT } \\
\text { throughout my daily work] }\end{array}$} & .213 & .239 & .538 \\
\hline & & & \\
\hline
\end{tabular}


Table 3. Means and standard deviations (in parentheses) of scores by professional groups

\begin{tabular}{|c|c|c|c|c|c|c|}
\hline & $\begin{array}{l}\text { Head Nurse } \\
(n=65) \\
\text { I }\end{array}$ & $\begin{array}{l}\text { GP } \\
(n=66) \\
\text { II }\end{array}$ & $\begin{array}{l}\text { Psychiatric nurse } \\
(n=56) \\
\text { III }\end{array}$ & $\begin{array}{l}\text { Psychologist } \\
(n=62) \\
\text { IV }\end{array}$ & $\begin{array}{l}\text { Psychiatrist } \\
(n=61) \\
\text { V }\end{array}$ & $\begin{array}{l}\text { Total } \\
(n=310)\end{array}$ \\
\hline Age* & $44.8(10.9)$ & 49.5 (11.6) & $43.4(12.3)$ & $40.3(10.1)$ & $43.1(9.8)$ & $44.4(11.3)$ \\
\hline Neg Emo & $3.22(0.84)$ & $3.22(0.91)$ & $2.83(1.07)$ & $2.10(0.75)$ & $2.38(0.70)$ & $2.76(0.97)$ \\
\hline Treat Dif & $3.30(0.69)$ & $3.43(0.82)$ & $3.10(0.77)$ & $2.58(0.59)$ & $2.99(0.62)$ & $3.09(0.76)$ \\
\hline Lack Emp & $2.53(0.62)$ & $2.71(0.57)$ & $2.64(0.72)$ & $2.64(0.62)$ & $2.91(0.70)$ & $2.69(0.65)$ \\
\hline CPU Tot & $4.61(1.20)$ & $4.46(1.09)$ & $4.46(1.06)$ & $4.90(0.79)$ & $4.80(0.94)$ & $4.64(1.04)$ \\
\hline Use Medtep & $4.99(1.44)$ & $4.94(1.29)$ & $5.02(1.30)$ & $5.62(0.95)$ & $5.51(0.79)$ & $5.21(1.21)$ \\
\hline Change Att & $4.18(1.43)$ & $3.95(1.31)$ & $3.71(1.42)$ & $3.84(1.42)$ & $3.87(1.45)$ & $3.92(1.40)$ \\
\hline Inten Use Medtep & $4.40(1.22)$ & $4.14(1.00)$ & $4.30(1.16)$ & $4.84(1.06)$ & $4.62(1.39)$ & $4.46(1.19)$ \\
\hline
\end{tabular}

Note: *29 participants (9.4\%) did not report their age; Neg Emo (Negative Emotions, BP-EAI); Treat Dif (Treatment Difficulties, BP-EAI); Lack Emp (Lack of Empathy, BP-EAI); CPU Tot (CPU Total Score); Use Medtep (Usefullness of Medtep DBT, CPU); Change Att (Change of Attitudes, CPU); Inten Use Medtep (Intention to use Medtep DBT, CPU)

grouped according to Black et al. (2011): four experience categories were created (one to four years, five to ten years, eleven to nineteen years, and twenty or more years of experience), along with four categories in terms of the number of BPD patients treated in the last year (zero to two, three to nine, ten to twenty four and twenty five or more). These groups were then compared in terms of the dependent variables (attitudes and perception of use).

T-tests were run for gender and for the two work areas (MHP versus PCHP). Three multivariate analyses of variance (MANOVA) were conducted to compare the different groups/categories with respect to the dependent variables: one compared the five professional groups, a second compared the four categories of amount of BPD patients treated in the last year, and a third compared the categories of years of experience in the mental health field. Finally, Pearson correlations between the three BP-EAI factors and the three CPU factors plus the total CPU score were conducted.

\section{Results}

\section{Comparison by gender}

Women showed significantly higher empathy (lower scores for the lack of empathy factor, $M=2.62, D T=$ $0.63)$ than men $(M=2.81, D T=0.66)(t=2.48, p=$ $.014)$. No other gender differences were found.

\section{Comparison by professional areas}

The descriptive statistics grouped by professional areas are depicted in table 3, and the results of the MANOVA Tests in table 4 . There were significant differences in negative emotions among professionals of different areas. Compared to other professionals, psychologists had significantly lower scores (except when compared to psychiatrists). Their scores were also lower than those of the PCHPs. There were also significant differences between the two healthcare areas $(t=7.76, p<.0001)$; PCHPs scored higher $(M=3.22, D T=0.87)$ than MHPs $(M=2.41, D T=0.89)$.

Regarding treatment difficulties, there were also significant differences among categories of profession-
Table 4. MANOVA and Scheffé test for professional groups

\begin{tabular}{|c|c|c|c|}
\hline Variable & $g l$ & $F$ & Scheffé Test \\
\hline Neg Emo & 4,305 & $21.31^{* * *}$ & $\begin{array}{l}\mathrm{I}>\mathrm{IV}^{* * *}, \mathrm{~V}^{* \star *} ; \mathrm{II}>\mathrm{IV}^{* \star *}, \mathrm{~V}^{* * *} \\
\mathrm{III}>\mathrm{IV}^{* \star *}\end{array}$ \\
\hline Treat Dif & 4,305 & $13.67^{* * *}$ & $\begin{array}{l}\mathrm{I}>\mathrm{IV}^{* * *} ; \mathrm{II}>\mathrm{IV}^{* * *}, \mathrm{~V}^{*} ; \mathrm{III}>\mathrm{IV}^{* *} \\
\mathrm{IV}<\mathrm{V}^{*}\end{array}$ \\
\hline Lack Emp & 4,305 & $3.06^{*}$ & $\mathrm{I}<\mathrm{V}^{*}$ \\
\hline CPU Tot & 4,305 & 2.28 & \\
\hline Use Medtep & 4,305 & $4.58^{\star \star}$ & $\mathrm{II}<\mathrm{IV}^{*}$ \\
\hline Change Att & 4,305 & 0.93 & \\
\hline $\begin{array}{l}\text { Inten Use } \\
\text { Medtep }\end{array}$ & 4,305 & $3.40^{\star}$ & $\mathrm{II}<\mathrm{IV}^{*}$ \\
\hline
\end{tabular}

als. Psychologists showed the lowest scores of all the groups of professionals. Psychiatrists showed less treatment difficulties than GPs. When comparing both healthcare areas, differences were again significant $(t=$ $5.79, p<.0001)$, with PCHPs $(M=3.37, D T=0.76)$ experiencing more treatment difficulties than MHPs $(M=2.88, D T=0.69)$.

Significant differences were also found in the third factor of the BP-EAI, lack of empathy, but the differences were only between psychiatrists and head nurses (see Table 4). The lack of empathy factor was the only one that showed no significant differences ( $t=$ $-1.49, p=.128$ ) when comparing the overall healthcare areas.

As far as the CPU factors, differences were only found with respect to the usefulness of Medtep DBT and the intention of using Medtep DBT (see Table 4); psychologists considered the application to be more useful than GPs. For the other two factors, there were no differences between any of the professions.

\section{Comparison with respect to quantity of patients treated}

There were significant differences in negative attitudes according to the quantity of BPD patients treated in the last year (Tables 5 and 6). The HPs who had seen 25 or more patients had lower rates of negative emotions than those who had treated between 10 and 24 and between three and nine (see Table 6). Those with 
Table 5. Means and standard deviations (in parentheses) of the scores grouped by quantity of patients treated

\begin{tabular}{|c|c|c|c|c|}
\hline & $\begin{array}{l}0 \text { to } 2 \text { BPD patients treated } \\
(n=31) \\
\text { I }\end{array}$ & $\begin{array}{l}3 \text { to } 9 \text { BPD patients treated } \\
(n=150) \\
\text { II }\end{array}$ & $\begin{array}{l}10 \text { to } 24 \text { BPD patients treated } \\
(n=95) \\
\text { III }\end{array}$ & $\begin{array}{l}25 \text { or more BPD patients treated } \\
(n=34) \\
\text { IV }\end{array}$ \\
\hline Age $^{*}$ & 39.7 (13.9) & $44.2(11.0)$ & 46.5 (10.9) & 43.9 (10.7) \\
\hline Neg Emo & $2.51(0.92)$ & $3.06(1.01)$ & $2.64(0.86)$ & $2.15(0.74)$ \\
\hline Treat Dif & $2.96(0.73)$ & $3.29(0.77)$ & $2.97(0.71)$ & $2.81(0.74)$ \\
\hline Lack Emp & $2.54(0.62)$ & $2.60(0.61)$ & $2.59(0.61)$ & $2.80(0.74)$ \\
\hline CPU Tot & $5.30(0.64)$ & $4.54(1.13)$ & $4.44(0.97)$ & $4.87(0.87)$ \\
\hline Use Medtep & $6.01(0.75)$ & $5.00(1.26)$ & $5.01(1.26)$ & $5.58(0.82)$ \\
\hline Change Att & $4.51(1.29)$ & $3.91(1.44)$ & $3.66(1.29)$ & $4.15(1.43)$ \\
\hline Inten Use Medtep & $4.91(1.08)$ & $4.44(1.26)$ & $4.34(1.20)$ & $4.35(1.20)$ \\
\hline
\end{tabular}

Note: *29 participants (9.4\%) did not report their age; Neg Emo (Negative Emotions, BP-EAI); Treat Dif (Treatment Difficulties, BP-EAI); Lack Emp (Lack of Empathy, BP-EAI); CPU Tot (CPU Total Score); Use Medtep (Usefullness of Medtep DBT, CPU); Change Att (Change of Attitudes, CPU); Inten Use Medtep (Intention to use Medtep DBT, CPU)

Table 6. MANOVA and Scheffé Test for quantity of patients treated

\begin{tabular}{llll}
\hline Variable & $\boldsymbol{g} \boldsymbol{l}$ & $\boldsymbol{F}$ & Scheffé Test \\
\hline Neg Emo & 3,306 & $12.29^{* * *}$ & $\mathrm{I}<\mathrm{II}$; II $>\mathrm{III}^{* *}, \mathrm{IV} * ; \mathrm{III}>\mathrm{IV}^{*}$ \\
Treat Dif & 3,306 & $7.29^{* * *}$ & $\mathrm{II}>\mathrm{III}^{* *}, \mathrm{IV}^{* *}$ \\
Lack Emp & 3,306 & $4.46^{* *}$ & $\mathrm{II}<\mathrm{III}^{*}$ \\
\hline CPU Tot & 3,306 & $5.06^{* *}$ & $\mathrm{I}>\mathrm{II}{ }^{* *}, \mathrm{III}^{*}$ \\
Use Medtep & 3,306 & $7.90^{* * *}$ & $\mathrm{I}>\mathrm{II}^{* * *}, \mathrm{III}{ }^{* *} ; \mathrm{II}<\mathrm{IV}^{*}$ \\
Change Att & 3,306 & 1.49 & \\
Inten Use Medtep & 3,306 & 1.51 & \\
\hline
\end{tabular}

Note: ${ }^{*} p<.05 ;{ }^{* *} p<.01 ;{ }^{* * *} p<.001 ; 0$ to 2 patients (I); 3 to 9 patients (II); 10 to 24 patients (III); 25 or more patients (IV); Neg Emo (Negative Emotions, BP-EAI); Treat Dif patients (III); 25 or more patients (IV); Neg Emo (Negative Emotions, BP-EAI); Treat D
(Treatment Difficulties, BP-EAI); Lack Emp (Lack of Empathy, BP-EAI); CPU Tot (CPU (Treatment Difficulties, BP-EAI); Lack Emp (Lack of Empathy, BP-EAI); CPU Tot (CPU
Total Score); Use Medtep (Usefullness of Medtep DBT, CPU); Change Att (Change of Total Score); Use Medtep (Usefullness of Medtep DBT, CPU); Change Att
Attitudes, CPU); Inten Use Medtep (Intention to use Medtep DBT, CPU)

two or less BPD patients treated scored lower than those who had treated between three and nine. Differences were also found between those who had treated from 10 to 24 patients and those with three to nine. In the treatment difficulties factor, too, significant differences were found, with HPs who had seen three to nine BPD patients scoring higher than those who had had 10 to 24 and 25 or more patients.

Regarding the CPU factors, those with two or fewer BPD patients treated got higher numbers for the total CPU score and for the usefulness of Medtep DBT than the groups including from three to 24 . It is also worth pointing out that in the usefulness factor those HPs who had treated between three and nine patients obtained lower scores than those with 25 or more (see Table 6).

\section{Comparison with respect to years of professional experience}

The results are depicted in Tables 7 and 8 . There were no significant differences related to attitude, but there were some with respect to perceived usefulness of the Medtep DBT. This was especially the case for the total CPU score and the score for usefulness of Medtep DBT, since all HPs with less than 20 years of experience scored significantly higher than those with more years of experience. In the other two factors the pattern was the same, but not all the comparisons turned out significant. In general, the less experienced the professionals are, the more potentially useful they perceive the application to be.

Finally, in order to evaluate the third hypothesis, the intercorrelations of the test variables (including overall score of CPU) were calculated and are depicted in table 9.

In general, stronger negative attitudes were associated with a more negative perception of Medtep DBT. Negative emotions showed a significant negative correlation with the perceived usefulness of Medtep DBT. Treatment difficulties were associated with lower perceived usefulness. Additionally, a lack of empathy showed negative correlations with change and inten-

Table 7. Means and standard deviations (in parentheses) grouped by years of experience in mental health

\begin{tabular}{|c|c|c|c|c|}
\hline & $\begin{array}{l}1 \text { to } 4 \text { years of work } \\
\text { experience } \\
(n=43) \\
\text { I }\end{array}$ & $\begin{array}{l}5 \text { to } 10 \text { years of work } \\
\text { experience } \\
(n=67) \\
\text { II }\end{array}$ & $\begin{array}{l}11 \text { to } 19 \text { years of work } \\
\text { experience } \\
(n=69) \\
\text { III }\end{array}$ & $\begin{array}{l}20 \text { or more years of work } \\
\text { experience } \\
(n=102) \\
\text { IV }\end{array}$ \\
\hline Age & $34.2(12.1)$ & $35.43(6.1)$ & $44.0(6.36)$ & $54.9(5.9)$ \\
\hline Treat Dif & $2.88(1.19)$ & $2.81(1.06)$ & $2.71(0.87)$ & $2.78(0.91)$ \\
\hline Lack Emp & $3.21(0.97)$ & $3.21(0.75)$ & $3.06(0.73)$ & $3.03(0.69)$ \\
\hline CPU Tot & $2.61(0.71)$ & $2.58(0.61)$ & $2.60(0.70)$ & $2.81(0.57)$ \\
\hline Use Medtep & $5.09(0.79)$ & $4.92(0.76)$ & $4.84(0.77)$ & $4.07(1.23)$ \\
\hline Change Att & $5.62(0.90)$ & $5.55(0.82)$ & $5.41(0.93)$ & $4.53(1.47)$ \\
\hline \multirow[t]{2}{*}{ Inten Use Medtep } & $4.37(1.31)$ & $4.05(1.27)$ & $4.24(1.23)$ & $3.41(1.48)$ \\
\hline & $4.95(1.06)$ & $4.82(1.28)$ & $4.43(1.10)$ & $4.00(1.12)$ \\
\hline
\end{tabular}

Note: Neg Emo (Negative Emotions, BP-EAI); Treat Dif (Treatment Difficulties, BP-EAI); Lack Emp (Lack of Empathy, BP-EAI); CPU Tot (CPU Total Score); Use Medtep (Usefullness of Medtep DBT, CPU); Change Att (Change of Attitudes, CPU); Inten Use Medtep (Intention to use Medtep DBT, CPU) 
Table 8. MANOVA and Scheffé Test for years of experience

\begin{tabular}{|c|c|c|c|}
\hline Variable & $g l$ & $F$ & Scheffé Test \\
\hline Neg Emo & 3,306 & 0.09 & \\
\hline Treat Dif & 3,306 & 0.93 & \\
\hline Lack Emp & 3,306 & 1.56 & \\
\hline $\mathrm{CPU}$ & 3,306 & $15.78^{\star * *}$ & $\mathrm{I}>\mathrm{IV}^{* * *} ; \mathrm{II}>\mathrm{IV}^{* * *} ; \mathrm{III}>\mathrm{IV}$ *** \\
\hline Use Medtep & 3,306 & $14.47^{* * *}$ & $\mathrm{I}>\mathrm{IV}^{* * *} ; \mathrm{II}>\mathrm{IV}^{* * *} ; \mathrm{III}>\mathrm{IV} \mathrm{V}^{* * *}$ \\
\hline Change Att & 3,306 & $7.45^{\star * *}$ & $\mathrm{I}>\mathrm{IV}^{\star *} ; \mathrm{III}>\mathrm{IV}^{\star *}$ \\
\hline Inten Use Medtep & 3,306 & $9.58^{\star \star *}$ & $\mathrm{I}>\mathrm{IV}^{* * *} ; \mathrm{II}>\mathrm{IV}^{* *}$ \\
\hline
\end{tabular}

Note: ${ }^{*} p<.05 ;{ }^{* *} p<.01 ;{ }^{* * *} p<.001 ; 1$ to 4 years (I); 5 to 10 years (II); 11 to 19 years (III); 20 or more years (IV); Neg Emo (Negative Emotions, BP-EAI); Treat Dif (Treatment Difficulties, BP-EAI); Lack Emp (Lack of Empathy, BP-EAI); CPU Tot (CPU Total Score); Use Medtep (Usefullness of Medtep DBT, CPU); Change Att (Change of Attitudes, CPU); Inten Use Medtep (Intention to use Medtep DBT, CPU)

tion of use. However, negative emotions showed a positive correlation with change of attitudes.

\section{Discussion}

\section{HPs' attitudes toward BPD patients}

In reference to the first hypothesis, we can see the following in the different factors of the BP-EAI: For the factor negative emotions, psychologists had the lowest scores, followed by psychiatrists. Both groups scored lower than PCHPs (see Table 3). When comparing both areas without differencing between groups, the results follow the same pattern. This is similar to the results obtained by Imbeau et al. (2014), even though in that case the lowest scores for positive perception of BPD patients were those of resident GPs; standard GPs were no different from mental health professionals. As far as nurses are concerned, Bodner et al. (2011) found no differences in terms of attitude between them and other professionals. The results of a larger study conducted a few years later (Bodner et al., 2015) turned out differently, as psychologists and psychiatrists scored lower than nurses, just as they did in this study. An illustrative example of this evidence was offered in a study by Woollaston and Hixenbaugh (2008), in which nurses described BPD patients as a destructive whirlwind: "It refers to nurses perceiving BPD patients as a powerful, dangerous, unrelenting and unstoppable force which leaves a trail of destruction in its wake". We believe these differences could be due to the fact that psychologists and psychiatrists receive more specific training, whereas nurses are much less trained in the nature and treatment of the disorder (Bodner et al., 2015). Commons and Lewis (2008) also noticed that psychologists who had received training did not improve significantly over their peers without training. However, nurses who had received training showed significant improvements over those who had not. This would support the idea that specific education or training, at least in the case of psychologists, is a factor that predisposes to them to adopt more positive attitudes. On the other hand, we also believe that nurses could be more easily accessible to patients in general than other HPs in an informal setting (spontaneous demands) and that therefore it would stand to reason that they would have more contact with BPD patients, which could feed into negative attitudes towards them.

Regarding the second factor of the BP-EAI, treatment difficulties, the results are similar to the previous factor (see Table 3). Psychologists go through fewer difficult experiences while treating BPD patients than other HPs. The same is true of psychiatrists, but only compared to GPs, not to nurses. Overall, we can observe that MHPs suffer from fewer difficulties. In any case, these difficulties follow the trends those reported by previous research stretching back a number of years (Sansone \& Sansone, 1995; Cleary et al., 2002, Eren \& Sahin, 2016), highlighting that this pattern has not changed over the past two decades.

Lastly, in the factor labelled lack of empathy, differences were found only between psychiatrists and head nurses, with higher scores for the latter. This data contradicts the findings of the existing literature. For example, Bodner et al. (2011) reported lower levels of empathy in nurses compared to the other HPs, including psychiatrists. Black et al. (2011) also obtained similar results, with nurses exhibiting less caring attitudes and concern for BPD patients. Elsewhere, prior studies had pointed out nurses' lack of empathy toward BPD patients (Gallop et al., 1989; McGrath \& Dowling, 2012). Possible explanations for this finding could lie in the cultural differences between samples (Stefanovics et al., 2016), but it might also stem from the fact that in the present study the differences were found in head nurses, whereas in the other studies either only mental health nurses participated (Bodner et al., 2011; Bodner et al., 2015; Gallop et al., 1989; McGrath \& Dowling, 2012) or there was an absence of specification (Black et al., 2011).

Generally, we can assert that the first hypothesis, regarding negative attitudes in different health care

Table 9. Pearson correlations between the BP-EAI factors and the CPU Total Score and their factors

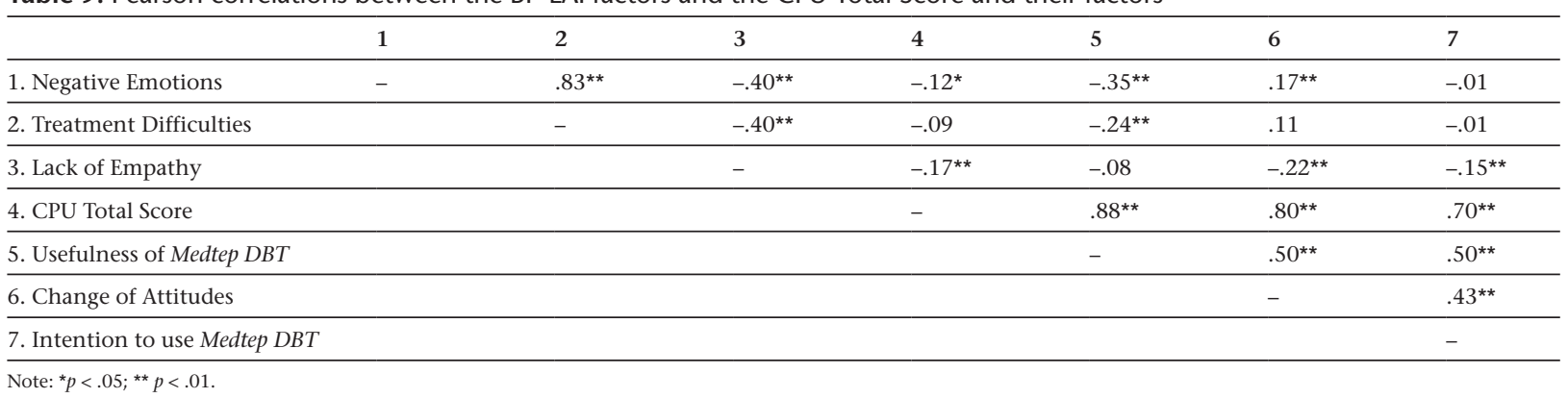


areas, is confirmed: PCHPs hold more negative attitudes than other professionals toward BPD patients. This could be due to the high prevalence of BPD patients in primary care (Gross et al., 2002) and to their tendency to seek help with more than one GP, as reported by Sansone et al. (2011). The authors argue that this tendency is due to BPD patients' volatile nature and to their lack of either a tolerance for frustration or boundaries. We consider that a possible explanation for the negative attitudes held by GPs and head nurses could stem from the vicious circle that is created by the constant intake of new BPD patients and the professionals' fear, many times warranted, that these patients will probably not show up for their next appointments. This factor exists in addition to the already disruptive characteristics of these patients (Koekkoek et al., 2009; Sansone \& Sansone, 1995). In any case, mental health area professionals also have frequent contact with BPD patients (Cleary et al., 2002), and they also have to deal with their disruptive characteristics. But an important difference is that PCHPs rarely receive any kind of training in the nature of the BPD or its treatment (Gross et al., 2002). This hypothesis is similar to the one regarding negative emotions in nurses. Along the same lines, we also believe that specific training can play a key role, allowing professionals, especially psychologists, to become more sensitive.

These differences among professionals notwithstanding, we found negative attitudes towards BPD patients in all professional groups. These results bear out those found in previous research, not only regarding the most studied group, nurses (Dickens, Lamont et al., 2016), but also with respect to the other ones (Arora, 2016).

Our hypothesis that less veteran HPs would hold more negative attitudes was not confirmed, which represents a similar result to the one reported by Bodner et al. (2015). We did find differences according to number of BPD patients treated in the last year, but the results are not conclusive, as negative attitudes did not increase with the number of patients treated. The present study does not concur with previous studies (Bodner et al., 2015; Black et al., 2011) and presents a third possibility: HPs who treat a moderate number of BPD patients (between three and nine) tend to hold more negative emotions and experience more treatment difficulties than HPs with either less or more patients. Contrary to this finding, HPs with fewer patients showed more empathy than those with a moderate number of patients. We propose two different reasons for these results: those with less contact with BPD patients do not have to deal as much with their disruptive features. Therefore, they hold less negative attitudes and experience fewer treatment difficulties. Those with many patients must deal more often with these characteristics and are probably pushed to develop a range of strategies to face them and reduce the resulting negative attitudes and treatment difficulties. We believe these strategies may lead to less emotional implication with the patient, resulting in less empathy.
This explanation must be taken with caution, as significant differences were not found between all groups in all factors.

Finally, gender was relevant only with respect to lack of empathy, a finding that coincides with previous research (Hojat, 2016), where male HPs showed less empathy than female HPs.

\section{Perception of using Medtep DBT}

The second hypothesis was partially confirmed: psychologists scored higher for almost all CPU factors than the other HPs, but these results are only significant when psychologists were compared to GPs. This result is not surprising, as therapy is conducted mainly by psychotherapists.

With respect to years of experience, our hypothesis was confirmed: those with less experience perceive a higher likelihood of using the tool. This might be due to the fact that they belong to the younger generation and have a more positive attitude towards new technologies in general. This is in line with data reported by Gagnon et al. (2016) and Graves et al. (2017), who have found that those with less experience in mHealth show less interest or willingness to use new mobile technologies. Therefore, we support the idea that younger HPs will be more used to mobile technologies and thus will show greater interest in using these tools in general (Kuhn et al., 2014) and Medtep DBT in particular.

Our hypothesis regarding number of BPD patients treated was partially confirmed: those with fewer patients scored higher for the usefulness of the app and for the overall factor, and as such they seem to be more interested in and willing to use the application. An explanation for this finding could be that these professionals feel less overburdened by their work and might be more willing to develop new skills with a new tool. A lighter workload was a factor pointed out by Gagnon et al. (2016) as a facilitator of the implementation of mHealth. However, we must admit that that those with many patients ( 25 or more) scored significantly higher than those with a moderate number of patients. This could be due to the fact that treating more patients might result in greater experience with the needs of those patients, and therefore these professionals might perceive the application as more useful.

\section{Negative attitudes and Medtep DBT}

Contrary to our third hypothesis, higher negative attitudes and more treatment difficulties were associated with lower perceived usefulness of the tool, lower empathy, lower perception of change and lower intention of using the tool. Thus, this variable could be interpreted as a barrier to the implementation of Medtep DBT. Lower empathy was also associated with lower intention of using the app. However, there was a small but positive correlation between negative emotions and change of attitudes, i.e. experiencing negative 
emotions toward BPD patients would result in the perception that such a tool could help professionals to change these emotions and attitudes. This could be an encouraging result, taking in to account the fact that negative emotions towards BPD patients are not uncommon (Dickens, Lamont et al., 2016; Sansone \& Sansone, 2013).

\section{Conclusions and future research}

The present study evidences the existence of negative attitudes helds by different HPs towards BPD patients in a Spanish sample. Therefore, like the authors of past studies (Bodner et al., 2015; O'Conell \& Dowling, 2013), we recommend further research into how to help HPs develop coping strategies to deal with the manifold challenges these patients present. We would also stress the need to train them in the nature and treatment of the disorder. There are several programs that have been shown to have good outcomes for MHPs (Knaak et al., 2015; Krawitz, 2004; Shanks et al., 2011) or nurses (Dickens, Hallet et al., 2016). GPs have been included in few studies (Keuroghlian et al., 2016), and therefore research efforts should also focus on this last group. As far as Medtep DBT use is concerned, it should be noted that lack of empathy, treatment difficulties and years of experience in mental health have been shown to be barriers to its implementation. However, it is encouraging that the HPs with the highest negative attitudes also perceive the application as a good tool to change them. In future research, the application should be tested and assessed in a broader field study focused on psychologists, since these professionals are the ones who usually conduct DBT. Thus, they appear to be the professionals who are most apt to use it.

\section{Limitations}

Although the average response rate was of $64 \%$, a quite high rate in this kind of study and slightly higher than some of its antecessors (Black et al., 2011; Bodner et al., 2015; Cleary et al., 2002; Commons \& Lewis, 2008), the results must be interpreted with caution, since there is a chance that the answers of those who did not participate would have been different. Furthermore, the questionnaires used are adaptations or ad hoc creations that were subjected to only preliminary psychometric analyses. Their internal consistency and validity have to be confirmed in future studies.

\section{Acknowledgements}

The author of the present study appreciates the help provided by the doctors María Irene Álvarez, José Cañete, José Luís Castro, Gracia González-Carpio, Javier Labad, Javier García Norro, Juan Carlos Pascual, Rafael Saenz, Joaquim Soler, Virginia Soria, Josefa María Panisello, Pedro Tárrega and Daniel Vega, Mrs. María Olvera and Mr. Eduardo Recuero, as well as the collaboration of all the participants in the study.

\section{References}

Arora, M. (2016). The development and validation of a self-report measure of staff attitudes to borderline personality disorder (Tesis doctoral). Recuperada de la base de datos Surrey Research Insight Open Access. (Núm. 811157)

American Psychiatric Association. (2013). Diagnostic and statistical manual of mental health disorders (5th ed.). Washington, DC. Author.

Bender, S. D., Dolan, R. T., Skodol, A. E., Sanislow, C. A., Dyck, I. R., McGlashan, T. H., ..., Gunderson, J. G. (2001). Treatment utilization by patients with personality disorders. American Journal of Psychiatry, 158, 295-302. doi: 10.1176/appi.ajp.158.2.295

Black, D. W., Blum, N., Pfohl, B., Mccormick, B., Allen, J., North, C. S., ..., Zimmerman, M. (2011). Attitudes toward borderline personality disorder: A survey of 706 mental health clinicians. CNS Spectrums, 16(3), 579-586. doi: 10.1017/S109285291200020X

Bodner, E., Cohen-Fridel, S. \& Iancu, I. (2011). Staff attitudes toward patients with borderline personality disorder. Comprehensive Psychiatry, 52, 548-555. doi: 10.1016/j.comppsych.2010.10.004

Bodner, E., Cohen-Fridel, S., Mashiah, M., Segal, M., Grinshpoon, A., Fischel, T. \& Iancu, I. (2015). The attitudes of psychiatric hospital staff toward hospitalization and treatment of patients with borderline personality disorder. BMC Psychiatry, 15(2). doi: 10.1186/s12888-014-0380-y

Bourke, M. E. y Grenyer, B. F. (2010). Psychotherapists' response to borderline personality disorder: A core conflictual relationship theme analysis. Psychoterapy Research, 20(6), 680-691. doi: 10.1080/10503307. 2010.504242

Braun, R., Catalani, C., Wimbush, J. \& Israelski, D. (2013). Community health workers and mobile technology: a systematic review of the literature. PLoS One, 8(6). doi: 10.1371/journal.pone.0065772

Breckler, S. J. (1984). Empirical validation of affect, behavior, and cognition as distinct components of attitude. Journal of Personality and Social Psychology, 47(6), 1191-1205. doi: 10.1037//0022-3514.47.6.1191

Brislin, R. W. (1970). Back-translation for cross-cultural research. Journal of Cross-Cultural Psychology, 1(3), 185-216. doi: 10.1177/135910457000100301

Cleary, M., Siegfried, N. \& Walter, G. (2002). Experience, knowledge and attitudes of mental health staff regarding clients with a borderline personality disorder. International Journal of Mental Health Nursing, 11(3), 186-191. doi: 10.1046/j.1440-0979.2002. 00246.x

Coid, J., Yang, M., Tyrer, P., Roberts, A. \& Ullrich, S. (2006). Prevalence and correlates of personality disorder in Great Britain. British Journal of Psychiatry, 188(5), 423-431. doi: 10.1192/bjp.188.5.423

Commons, A. J. (2009). Effectiveness of education programs in changing clinicians' attitudes toward treating borderline personality disorder. Psychiatric Services, 60(8), 1128-1131. doi: 10.1176/appi.ps.60.8.1128 
Commons, A. J. \& Lewis, A. J. (2008). Professional attitudes towards deliberate self-harm in patients with borderline personality disorder. Australian and New Zealand Journal of Psychiatry, 42(7), 578-584. doi: 10.1080/00048670802119796

Cristea, I. A., Gentili, C., Cotet, C. D., Palomba, D., Barbui, C. \& Cuijpers, P. (2017). Efficacy of psychotherapies for borderline personality disorder. A Systematic Review and Meta-analysis. JAMA Psychiatry, 74(4), 319-328. doi: 10.1001/jamapsychiatry.2016.4287

Deans, C. \& Meocevic, E. (2006). Attitudes of registered psychiatric nurses towards patients diagnosed with borderline personality disorder. Contemporary Nurse, 21(1), 43-49. doi: 10.5172/conu.2006.21.1.43

Dickens, G., Hallet, N. \& Lamont, E. (2016). Interventions to improve mental health nurses' skills, attitudes and knowledge related to people with a diagnosis of borderline personality: Systematic review. International Journal of Nursing Studies, 56: 114-127. doi: 10.1016/2015.10.019

Dickens, G., Lamont, E. \& Gray, S. (2016). Mental health nurses' attitudes, behavior, experience and knowledge regarding adults with a diagnosis of borderline personality disorder: systematic, integrative literature review. Journal of Clinical Nursing, 25(13-14), 114-127. doi: 10.1111/jocn.13202

Eren, N. \& Sahin, S. (2016). An evaluation of the difficulties and attitudes mental health professionals experience with people with personality disorders. Journal of Psychiatric and Mental Health Nursing, 23(1), 22-36. doi: 10.1111/jpm.12257

Forsyth, A. (2007). The effects of diagnosis and noncompliance attributions on therapeutic alliance processes in adult acute psychiatric settings. Journal of Psychiatric and Mental Health Nursing, 14(1), 33-40. doi: 10.1111/j.1365-2850.2007.01036.x

Fraser, K. \& Gallop, R. (1993). Nurses' confirming/ disconfirming responses to patients diagnosed with borderline personality disorder. Archives of Psychiatric Nursing, 7(6), 336-341. doi: 10.1016/08839417(93)90051-W

Gagnon, M. P., Ngangue, P., Payne-Gagnon, J. \& Desmartis, M. (2016). mHealth adoption by healthcare professionals: a systematic review. Journal of the American Medical Informatics Association, 23(1), 212220. doi: 10.1093/jamia/ocv052

Gallop, R., Lancee, W. J. \& Garfinkel, P. (1989). How nursing staff respond to the label "borderline personality disorder". Hospital \& community psychiatry, 40(8), 815-819. doi: 10.1176/ps.40.8.815

Giannouli, H., Perogamvros, L., Berk, A., Svigos, A. \& Vaslamatzis, G. (2009). Attitudes, knowledge and experience of nurses working in psychiatric hospitals in Greece, regarding borderline personality disorder: a comparative study. Journal of Psychiatric and Mental Health Nursing, 16(5), 481-487. doi: 10.1111/j.13652850.2009.01406.x

Grant, B. F., Chou, P., Goldstein, R. B., Huang, B., Stinson, F. S., Saha, T., ... Ruan, W. J. (2008). Prevalence, correlates, disability, and comorbidity of DSM-IV borderline personality disorder: results from the Wave 2 national epidemiologic survey on alcohol and related conditions. Journal of Clinical Psychiatry, 69(4), 533-545. doi: 10.4088/JCP.v69n0404

Graves, M., Doucet, S., Dubé, A \& Johnson, M. (2017). Health professionals' and patients' perceived barriers and facilitators to collaborating when communicating through the use of information and communication technologies. Journal of Interprofessional Education \& Practice. doi: 10.1016/j.xjep.2017.03.002

Greenhalgh, T., Robert, G., MacFarlane, F., Bate, P. \& Kyriakidou, O. (2004). Diffusion of innovations in service organizations: systematic review and recommendations. The Milbank Quarterly, 82(4), 581-629. doi: 10.1111/j.0887-378X.20004.00325.X

Gross, R., Olfson, M., Gameroff, M., Shea, S., Feder, A., Fuentes, M., ... Weissman, M. M. (2002). Borderline personality disorder in primary care. Archives on Internal Medicine, 162(1), 53-60. doi: 10.1001/archinte.162.1.53

Harrison, V., Proudfoot, J., Wee, P. P., Parker, G., Pavlovic, D. H. \& Manicavasagar, V. (2011). Mobile mental health: review of the emerging field and proof of concept study. Journal of Mental Health, 20(6), 509524. doi: 10.3109/09638237.2011.608746

Hauck, J. L., Harrison, B. E. \& Montecalvo, A. L. (2013). Psychiatric nurses' attitudes toward patients with borderline personality disorder experiencing deliberate self-harm. Journal of Psychosocial Nursing and Mental Health Services, 51(1), 20-29. doi: 10.3928/02793695-20121204-02

Hazelton, M., Rossiter, R. \& Milner, J. (2006). Managing the "unmanageable": Training staff in the use of dialectical behavior therapy for borderline personality disorder. Contemporary Nurse, 21(1), 120-130. doi: 10.5172/conu.2006.21.1.120

Herschell, A. D., Lindhiem, O. J., Kogan, J. N., Celedonia, K. L. \& Stein, B. D. (2014). Evaluation of an implementation initiative for embedding dialectical behavior therapy in community settings. Evaluation and Program Planning, 43, 55-63. doi: 10.1016/j.evalprogplan.2013.10.007

Hojat, M. (2016). Empathy and gender: are men and woman complementary or opposite sexes? En empathy in health professions education and patient care (pp. 169-187). New York, NY: Springer International Publishing.

Imbeau, D., Bouchard, S., Terradas, M. M. \& Simard, V. (2014). Attitudes des médecins omnipraticiens et des résidents en médicine familiale à l'endroit des personnes souffrant d'un trouble de personnalité limite. Sante Mental au Québec, 39(1), 273-289. doi: 10.7202/1025917ar

James, P. D. \& Cowman, S. (2007). Psychiatric nurses' knowledge, experience and attitudes towards clients with borderline personality disorder. Journal of Psychiatric and Mental Health Nursing, 14(7), 670-678. doi: 10.1111/j.1365-2850.2007.01157.x

Jobst, A., Hörz, S., Birkhofer, A., Martius, P. \& Rentrop, M. (2010). Psychotherapists' attitudes towards the 
treatment of patients with borderline personality disorder. Psychotherapie, Psychosomatik, Medizinische Psychologie. 60(3-4), 126-131. doi: 10.1055/s-00291220764

Katsakou, C. \& Pistrang, N. (2017). Clients' experiences and recovery in borderline personality disorder: A meta-synthesis of qualitative studies. Psychotherapy Research. 1-18. doi: 10.1080/10503307.2016.1277040

Kazdin, A. E. \& Blasé, S. L. (2011). Rebooting Psychotherapy Research and Practice to Reduce the Burden of Mental Illness. Perspectives on Psychological Science, 6(1), 21-37. doi: 10.1177/1745691610393527

Keuroghlian, A. S., Palmer, B. A., Choi-Kain, L. W., Borba, C. P. C., Links, P. S. \& Gunderson, J. G. (2016). The effect of attending good psychiatric management (GPM) workshops on atittudes toward patients with borderline personality disorder. Journal of Personality Disorders, 30(4), 567-576. doi: 10.1521/pedi_2015_ 29_206

Knaak, S., Szeto, A. C. H., Fitch, K. \& Patten, S. (2015). Stigma towards borderline personality disorder: effectiveness and generalizability of an anti-stigma program for healthcare providers using a pre-post randomized design. Borderline Personality Disorder and Emotion Dysregulation, 2(9), 1-8. doi: 10.1186/s40479015-0030-0

Koekkoek, B., van Meijel, B., Schene, A. \& Hutschemaekers, G. (2009). Clinical problems in community mental health care for patients with severe borderline personality disorder. Community Mental Health Journal, 45(6), 508-516. doi: 10.1007/s10597-0099259-7

Krawitz, R. (2004). Borderline personality disorder: attitudinal change following training. Australian and New Zealand Journal of Psychiatry, 38(7), 554-559. doi: 10.1080/j.1440-1614.2004.01409.x

Krawitz, R. \& Batcheler, M. (2006). Borderline personality disorder: a pilot survey about clinician views on defensive practice. Australasian Psychiatry, 14(3), 320-322. doi: 10.1080/j.1440-1665.2006.02297.x

Kuhn, E., Eftekhari, A., Hoffman, J. E., Crowley, J. J., Ramsey, K. M., Reger, M. R. \& Ruzek, J. I. (2014). Clinician perceptions of using a smartphone app with prolonged exposure therapy. Administration and Policy in Mental Health and Mental Health Services Research, 41(6), 800-807. doi: 10.1007/s10488-0130532-2

Lam, D. C. K., Poplavskaya, E. V., Salkovskis, P. M., Hogg, L. I. \& Panting, H. (2016). An experimental investigation of the impact of personality disorder diagnosis on clinicians: can we see past the borderline? Behavioural and Cognitive Psychotherapy, 44(3), 361-373. doi: 10.1017/S1352465815000351

Lam, D. C. K., Salkovskis, P. M. \& Hogg, L. I. (2016). "Judging a book by its cover": An experimental study of the negative impact of a diagnosis of borderline personality disorder on clinicians' judgements of uncomplicated panic disorder. British Journal of Clinical Psychology, 55(3), 253-268. doi: 10.1111/ bjc.12093
Lawn, S. \& McMahon, J. (2015). Experiences of care by Australians with a diagnosis of borderline personality disorder. Journal of Psychiatric and Mental Health Nursing, 22(7), 510-521. doi: 10.1111/jpm.12226

Leigh, S. \& Flatt, S. (2015). App-based psychological interventions: friend or foe? Evidenced Based Mental Health, 18(4), 97-99. doi: 10.1136/eb-2015-102203

Lenzenweger, M. F., Lane, M. C., Loranger, A. W. \& Kessler, R. C. (2007). DSM-IV personality disorders in the National comorbidity survey replication. Biological Psychiatry, 62(6), 553-564. doi: 10.1016/j. biopsych.2006.09.019

Linehan, M. M. (1987). Dialectical behavior therapy: a cognitive behavioral approach to parasuicide. Journal of Personality Disorders, 1(4), 328-333. doi: 10.1521/pedi.1987.1.4.328

Linehan, M. M., Korslund, K. E., Harned, M. S., Gallop, R. J., Lungu, A., Neacsiu, A. D., ... Murray-Gregory, A. M. (2015). Dialectical behavior therapy for high suicide risk in individuals with borderline personality disorder: a randomized clinical trial and component analysis. JAMA Psychiatry, 72(5), 475-482. doi: 10.1001/jamapsychiatry.2014.3039

Luxton, D. D., McCann, R. A., Bush, N. E., Mishkind, M. C. \& Reger, G. M. (2011). mHealth for mental health: integrating smartphone technology in behavioral healthcare. Professional Psychology: Research and Practice, 42(6), 505-512. doi: 10.1037/10024485

Markham, D. (2003). Attitudes towards patients with a diagnosis of "borderline personality disorder": Social rejection and dangerousness. Journal of Mental Health, 12(6), 595-612. doi: 10.1080/096382303100 01627955

Markham, D. \& Trower, P. (2003). The effects of the psychiatric label "borderline personality disorder" on nursing staff's perceptions and causal attributions for challenging behaviors. British Journal of Clinical Psychology, 42(3), 243-256. doi: 10.1348/0144665 0360703366

Marley J. \& Farooq, S. (2015). Mobile telephone apps in mental health practice: uses, opportunities and challenges. BJPsych Bulletin, 39(6), 288-290. doi: 10.1192/pb.bp.114.050005

Marzano, L., Bardill, A., Fields, B., Herd, K., Veale, D., Grey, N. \& Moran, P. (2015). The application of mHealth to mental health: opportunities and challenges. Lancet Psychiatry, 2(10), 942-948. doi: 10.1016/S2215-0366(15)00268-0

McGrath, B., \& Dowling, M. (2012). Exploring registered psychiatric nurses' responses towards service users with a diagnosis of borderline personality disorder. Nursing Research and Practice. doi: 10.1155/2012/601918 mHealth. (Sin fecha). En Wikipedia. Recuperado el 20 de septiembre de 2017 de https://en.wikipedia.org/ wiki/MHealth

Muñiz, J., Elosua, P. \& Hambleton, R. K. (2013). Directrices para la traducción y adaptación de los tests: segunda edición. Psicothema, 25(2), 151-157. doi: 10.7334/psicothema2013.24

Naslund, J. A., Marsch, L. A., McHugo, G. J. \& Bartels, S. J. (2015). Emerging mHealth and eHealth inter- 
ventions for serious mental illness: a review of the literatura. Journal of Mental Health, 24(5), 321-332. doi: 10.3109/09638237.2015.1019054

O'Conell, B. \& Dowling, M. (2013). Community psychiatric nurses' experiences of caring for clients with borderline personality disorder. Mental Health Practice, 17(4), 27-33. doi: 10.7748/mhp2013.12.17. 4.27.e845

Olff, M. (2015). Mobile mental health: a challenging research agenda. European Journal of Psychotraumatology, 6. doi: 10.3402/ejpt.v6.27882

Panos, P. T., Jackson, J. W., Hasan, O. \& Panos, A. (2014). Meta-analysis and systematic review assessing the efficacy of dialectical behavior therapy (DBT). Research on Social Work Practice, 24(2), 213-223. doi: 10.1177/1049731513503047

Petty, R. E., Wegener, D. \& Fabrigar R.L. (1997). Attitudes and attitude change. Annual Review of Psychology, 48(1), 609-647. doi: 10.1146/annurev.psych.48.1.609

Piccinino, S. (1990). The nursing challenge. Borderline patients. Journal of Psychosocial Nursing and Mental Health Services, 28(4), 22-7. doi: 10.3928/0279-369519900401-08

Powell, A. C., Landman, A. B. \& Bates, D. W. (2014). In a search of a few good apps. JAMA, 311(18), 18511852. doi: 10.1001/jama.2014.2564

Powers, A.D. \& Oltmanns, T.F. (2012). Personality disorders and physical health: A longitudinal examination of physical functioning, healthcare utilization, and health-related behaviors in middle-aged adults. Journal of Personality Disorders, 26(4), 524-538. doi: 10.1521/pedi.2012.26.4.524

Price, M., Yuen, E. K., Goetter, E. M., Herbert, J. D., Forman, E. M., Acierno, R. \& Ruggiero, K. J. (2014). mHealth: a mechanism to deliver more accessible, more effective mental health care. Clinical Psychology \& Psychotherapy, 21(5), 527-436. doi: 10.1002/ cpp. 1855

PricewaterhouseCoopers. (2012). Emerging mHealth: paths for grow. Recuperado de https://www.pwc.com/ gx/en/healthcare/mhealth/assets/pwc-emergingmhealth-full.pdf

Qiang, C. Z., Yamamichi, M., Hausman, V., Miller, R. \& Altman, D. (2012). Mobile applications for the health sector. (World Bank informe 72604). Recuperado de http://siteresources.worldbank.org/INFORMATIONANDCOMMUNICATIONANDTECHNOLOGIES/ Resources/mHealth_report.pdf

Quirk, S. E., Berk, M., Chanen, A. M., KoivumaaHonkanen, H., Brennan-Olsen, S. L., Pasco, J. A. \& Williams, L. J. (2015). Population prevalence of personality disorder and associations with physical health comorbidities and health care service utilization: A Review. Personality Disorders: Theory, Research and Treatment. 7(2), 136-146. doi: 10.1037/per0000148 research2guidance. (2014). mHealth App developers economics 2014: the state of the art of mHealth app publishing. Recuperado de http://www.research2guidance.com/r2g/research2guidance-mHealth-AppDeveloper-Economics-2014.pdf research2guidance. (2016). mHealth app developers economics 2016: the current status and trends of the mHealth app market. Recuperado de http://research2 guidance.com/wp-content/uploads/2016/10/ mHealth-App-Developer-Economics-2016-v17-Preview-1-1.pdf

Rogers, B. \& Dunne, E. (2011). "They told me I had this personality disorder... All of a sudden I was wasting their time": Personality disorder and the inpatient experience. Journal of Mental Health, 20(3), 226-233. doi: 10.3109/09638237.2011.556165

Sansone, R. A., Farukhi, S. \& Wiederman, M. W. (2011). Utilization of primary care physicians in borderline personality. General Hospital Psychiatry, 33(4), 343346. doi: 10.1016/j.genhosppsych.2011.04.006

Sansone, R. A. \& Sansone, L. A. (1995). Borderline personality disorder. Interpersonal and behavioral problems that sabotage treatment success. Postgraduate medicine, 97(6), 169-179

Sansone, R. A. \& Sansone, L. A. (2013). Responses of mental health clinicians to patients with borderline personality disorder. Innovations in Clinical Neuroscience, 10(5-6), 39-43.

Servais, L. M. \& Saunders, S. M. (2007). Clinical psychologists' perceptions of persons with mental illness. Professional Psychology: Research and Practice, 38(2), 214-219. doi: 10.1037/0735-7028.38.2.214

Shanks, C., Pfohl, B., Blum, N. \& Black, D. W. (2011). Can negative attitudes toward patients with borderline personality disorder be changed? The effect of attending a STEPPS workshop. Journal of Personality Disorders, 25(6), 806-812. doi: 10.1521/pedi.2011.25. 6.806

Silva, B. M. C., Rodrigues, J. J. P. C., Díez, I. T., LópezCoronado, M. \& Saleem, K. (2015). Mobile-health: A review of current state in 2015. Journal of Biomedical Informatics, 56, 265-272. doi: 10.1016/j.jbi.2015.06. 003

Smith, M. B. (1947). The personal setting of public opinions: a study of attitudes toward russia. Public Opinion Quarterly, 11(4), 507-523. doi: 10.1093/ poq/11.4.507

Stefanovics, E., He, H., Ofori-Atta, A., Tavares, M., Rocha, H., Makanjuola, V., ... Rosenheck, R. (2016). Cross-national analysis of beliefs and attitude toward mental illness among medical professionals from five countries. Psychiatric Quarterly, 87(1), 63-73. doi: 10.1007/211126-015-9363-5

Suñol, J., Panisello, J.M., Castell, E., Tárraga, J.P., Sánchez, C. \& Pérez V. (2017). "Medtep DBT": A dialectical behavior therapy native app and web platform for borderline personality disorder patients and their therapists. Universal Journal of Public Health, 5(3): 110-118. doi: 10.13189/ujph.2017.050305

Tomko, R. L., Trull, T. J., Wood, P. K. \& Sher, K. J. (2014). Characteristics of borderline personality disorder in a community sample: comorbidity, treatment utilization, and general functioning. Journal of Personality Disorders, 28(5), 743-750. doi: 10.1521/pedi_2012_ 26_093 
Tomlinson, M., Roterham-Borus, M. J., Swartz, L. \& Tsai, A. C. (2013). Scaling up mHealth: where is the evidence? PLoS Medicine, 10(2). doi: 10.1371/journal. pmed.1001382

Torgersen, S., Kringlen, E. \& Cramer, V. (2001). The prevalence of personality disorders in a community sample. Archives of General Psychiatry, 58(6), 590-596. doi: 10.1001/archpsyc.58.6.590

Torous, J., Chan, S. R., Tan, S. Y. M., Behrens, J., Mathew, I., Conrad, E. J., ... Keshavan, M. (2014). Patient smartphone ownership and interest in mobile apps to monitor symptoms of mental health conditions: a survey in four geographically distinct psychiatry clinics. JMIR Mental Health, 1(1). doi: 10.2196/mental.4004

Torous, J., Friedman, R. \& Keshavan, M. (2014). Smartphone ownership and interest in mobile applications to monitor symptoms of mental health conditions. JMIR mHealth and uHealth, 2(1). doi: 10.2196/mhealth.2994

Torous, J., Levin, M., Ahern, D. \& Oser, M. (2017) Cognitive behavioral mobile applications: clinical studies, marketplace overview, and research agenda. Cognitive and Behavioral Practice, 24(2), 215-225. doi: 10.1016/j.cbpra.2016.05.007

Torous, J. \& Powell, A. C. (2015). Current research and trends in the use of smartphone applications for mood disorders. Internet Interventions, 2(2), 169-173. doi: 0.1016/j.invent.2015.03.002

Torous, J., Staples, P. \& Onnela, J. P. (2015). Realizing the potential of mobile mental health: new methods for new data in psychiatry. Current Psychiatry Reports,
17(8). doi: 10.1007/s11920-015-0602-0

Trull, T. J., Jahng, S., Tomko, R. L., Wood, P. K. \& Sher, K. J. (2010). Revised nesarc personality disorder diagnoses: gender prevalence, and comorbidity with substance dependence disorders. Journal of Personality Disorders, 24(4), 412-426. doi: 10.1521/pedi.2010. 24.4.412

Veysey, S. (2014). People with a borderline personality disorder diagnosis describe discriminatory experiences. New Zealand Journal of Social Sciences Online, 9(1), 20-35. doi: 10.1080/1177083X.2013.871303

Woollaston, K. \& Hixenbaugh, P. (2008). "Destructive Whirlwind": nurses' perceptions of patients diagnosed with borderline personality disorder. Journal of Psychiatric and Mental Health Nursing, 15(9), 703-709. doi: 10.1111/j.1365-2850.2008.01275.x

World Health Organization. (2011). mHealth: new horizons for health through mobile technologies. Recuperado de http://www.who.int/goe/publications/goe_ mhealth_web.pdf

Zanarini, M. C., Frankenburg, F. Hennen, J. \& Silk, K. R. (2004). Mental health service utilization by borderline personality disorder patients and Axis II comparison subjects followed prospectively for 6 years. Journal of Clinical Psychiatry, 65(1), 28-36. doi: 10.1176/appi.ajp.161.11.2108

Zanarini, M. C., Horwood, J., Wolke, D., Waylen, A., Fitzmaurice, G. \& Grant, B. F. (2011). Prevalence of DSM-IV borderline personality disorder in two community samples: 6.330 English 11-year olds and 34.653 American adults. Journal of Personality Disorders, 25(5), 607-619. doi: 10.1521/pedi.2011.25.5.60 